\section{Miners' 'Claims' and Native Lands in Kenya}

Elsewhere in this issue (p. 37), we have discussed the grave situation which may arise through the proposed legislation dealing with gold prospecting in native reserves in Kenya. The explanatory memorandum issued by the Chief Native Commissioner of Kenya Colony to the natives likely to be affected has now been published in the Times (Jan. 5). It would appear to be fundamentally opposed to the whole conception and purpose of the institution of a native reserve, and is likely to be thoroughly disturbing to the minds of natives nervous for their rights. It seems that no attempt will be made to segregate the native or to control the siting of mining claims. European interpenetration of native holdings on the reserve will be complete. The natives are informed that they may expect to see their holdings 'pegged', or such part of them as may be required, wherever it is thought worth while to look for gold, and their huts and shambas may be destroyed; while they are invited to squat on their neighbours' land and make money, pending the vacation of their own land at some indefinite date, by working in the mines. It is also suggested that natives may sell to the miner meat, chickens' eggs and vegetables, but this applies, presumably, to those who have not been dispossessed of their land. Sir Edward Grigg has rebuked the Archbishop of Canterbury for suggesting that "African interests . . . are likely to receive better and wiser consideration from 'public opinion' in this country than from the Government of the Colony" ; but the anthropologist asks "Quis custodiet ipsos custodes"? This unfortunate memorandum, issued, be it marked, by the department responsible for the well-being of the native, passes over all that has been achieved by scientific study of native races and of the problems that arise from their unchecked contact with Europeans.

\section{Liverpool School of Tropical Medicine}

Dr. J. Middlemass Hunt, who held the post of honorary dean of the Liverpool School of Tropical Medicine for many years, has, by the terms of his will, emphasised the great interest that he took in research on tropical diseases. He has made a bequest of $£ 20,000$ to the University of Liverpool in order to provide for the endowment of the chair of tropical diseases of Africa. This will greatly strengthen the position of the laboratory of the School in West Africa originally established under the will of the late Sir Alfred Jones. In the Sir Alfred Lewis Jones's bequest, a sum was set aside for the specific purpose of building a research laboratory in Sierra Leone, West Africa, but no endowment was available. The building was erected as soon as possible after the War, the first director of the laboratory and first holder of the chair of tropical diseases of Africa being Prof. D. B. Blacklock, who remained in charge from 1921 until 1929. The present director and holder of the chair is Prof. R. M. Gordon. The laboratory has a normal staff of three which, in exceptional times, has been increased to five, and combines research on West African diseases with pathological investiga- tions of a routine nature connected with these diseases. Dr. Middlemass Hunt was impressed by the fact that this overseas development of the Liverpool School of Tropical Medicine lacks any endowment and his generous bequest is evidence of his desire to initiate the consolidation and extension of the work of this important branch of the School.

\section{Institute of British Geographers}

THE work, extending over the past two years, of various preliminary committees was brought to a conclusion on January 3 when the Institute of British Geographers held its first meeting and elected a council and officers. The initial membership is open to all present members of the staffs of university departments of geography in Britain ; in the future, membership will be by election. With one possible exception, all universities, as well as a large number of colleges of university rank, in Great Britain have now departments of geography and there is thus an obvious need for co-ordinating the teaching and research work of their staffs and for permitting an exchange of views on matters of particular interest in the furtherance of the subject in the universities. The Institute is thus in no way a rival to existing bodies. In discussing problems of special interest to themselves, it is clearly not the desire of university geographers to lose the contact which they have with administrators, travellers and surveyors, amongst others, who provide so much of their material, through the Royal Geographical Society ; or with the teachers who have charge of the school training of the rising generation, through the Geographical Association. At the first meeting, papers were read, on "Soils", by Mr. A. Stevens (Glasgow), on the geography of the Arab Empire in Europe, by Mr. W. G. East (London), and on a comparison between the iron industries of Northamptonshire and Lorraine, by Mr. S. H. Beaver (London). The council and officers elected are: President: Prof. C. B. Fawcett (University College, London); Hon. Secretary and Treasurer: Mr. A. A. Miller (Reading); Hon. Assistant Secretary: Dr. H. A. Matthews (Birkbeck College, London); Council: Mr. J. N. L. Baker (Oxford); Dr. R. O. Buchanan (University College, London); Prof. H. J. Fleure (Manchester); Prof. Ll. Rodwell Jones (London School of Economics); Prof. P. M. Roxby (Liverpool) and Dr. S. W. Wooldridge (King's College, London).

\section{Centenary of Friedrich Koenig, I774-1833}

FEw things have assisted the spread of knowledge more than the invention of printing from moveable types, the mass production of paper and the introduction of the power-driven printing machine, the last of which we owe to the German printer Friedrich Koenig, whose centenary occurs on January 17. He was born at Eisleben on April 17, 1774, and, after attending school, was apprenticed to a printer of Leipzig and then worked as a journeyman. His first improvements were made in connexion with the ordinary hand press. To further his projects he came to England in 1806, and it was soon after this that 
he met his countryman, Andreas Friedrich Bauer (1783-1860), who possessed the mechanical skill Koenig lacked. Four patents were taken out between 1810 and 1814 and from these came the powerdriven flat bed printing machine in which the paper was pressed against the type by a cylindrical roller. Through John Walter (1776-1847), two of Koenig's machines were installed for printing the Times, and with the appearance of the issue of November 28, 1814, a new era in newspaper production began. Koenig's success, however, was but the prelude to a long struggle against difficulties. Returning to Germany with Bauer in 1817, he founded a works for the building of printing machines at Oberzell near Würzburg, only to find it next to impossible to obtain properly skilled artisans. Five years indeed passed before the partners completed their first German printing machine, and throughout his life Koenig met with little but adversity. He died at Oberzell at the age of fifty-eight years. The business was carried on by Bauer and relations, and afterwards gained a wide reputation. The speed of an early Koenig machine was about two thousand sheets an hour. Improvements by Cowper and Applegarth raised the speed to 5,000-10,000 sheets an hour, the Hoes of America then built machines doubling the capacity and to-day the rate of printing is some fifty times as fast as that in 1814 .

\section{Royal Academy Winter Exhibition}

OF the Winter Exhibition of the Royal Academy, illustrating the works of members who have recently died, one of the oldest academicians remarked that in no country could be brought together such a fine collection of sound painting from the work of men recently with us. Apart from merit, there is also the pleasure of seeing again pictures notable in their day, some of enduring appeal, while others markedly exhibit the fashion of another age. Both as regards number and interest, Orpen's pictures should be mentioned first. From the student-study, the "Hamlet Play Scene", with its dull browns and reds, the transition can be traced to the clear coldness of the colours in his recent portraits, well on the way to be 'old masters'. One of the most striking, that of the late Sir William McCormick (No. 87), will delight many readers of NATURE. Mid-Victorian days are recalled by the work of the late president, when the fashion was for stained glass windows, flowing garments and red-gold hair. Time was when in every annual exhibition one or more of Harry Tuke's pictures of bathing boys appeared. Here we have a collection of them and find them still pleasing, while Wyllie's sea-pictures are full of life and colour. In contrast with these the Lambert pictures seem wanting in atmosphere, but that of the Red Girl (No. 251) and Round Mirror (No. 260) should be noticed.

Perhaps too low in tone for modern taste are the pictures of La Thangue, in which French influence is prominent. Great variety is shown in the works of Greiffenhagen, some of it almost heraldic, but including several character studies (Nos. 304, 306 and 325). Of contrast between an earlier and a later style there is none more violent than is exhibited in the work of Sims, from a delicate and poetic touch portraying in delicate mother-of-pearl tints the "Light that never was on Sea or Land", to strange conceptions in harsh reds, yellows and blacks. Many examples of the well-known work of Ricketts as a book-designer will be found in a case in Room IX, while his paintings are hung in the same room against a rose background. Great restraint is shown in the water-colours of David Muirhead, but more freedom is exhibited in his oil-paintings $(543,547)$.

\section{Education for Industrial Management}

Over the signatures of Lord Rutherford, Sir William Bragg, Sir Josiah Stamp, Lord Eustace Percy, Lord Amulree, Sir Herbert Austin, Prof. C. E. Inglis, Sir Francis Goodenough and others, an important manifesto on "The Management Factor in Industry" was issued on December 31. The manifesto was drafted by a small committee all the members of which are voluntary workers in one or more societies or institutions dealing with functional phases of management. Of this committee, Mr. E. S. Byng was chairman and Mr. S. Townsend, honorary secretary. The manifesto emphasises the urgent need for a full appreciation of the national importance of the management function and of the rapid diffusion of management knowledge, and directs particular attention to the quality of industrial management. Systematic education for management is asserted to be one of the chief steps required to assure Britain's industrial future, and neglect of this factor is frequently responsible for our managers' failure to interpret the progress of science in terms of their own undertakings. The manifesto directs attention to the development of a science of management and points out that to an increasing degree men of high personal character and cultured vision are finding in manage. ment a sphere of high social service. They are using the resources and methods of science to raise the effectiveness of their contribution to the organisation and direction of industry.

WHILE on this side the application of scientific methods to the functions and processes of business organisation promotes greater efficiency, establishes standards, and replaces haphazard effort by the deliberate pursuit of predetermined objectives, management is also an art involving co-operation and understanding of the human factor, so that acceptance of the scientific principles and loyal co-operation in the plans of the organisation may be secured from all its members. Skill in technique; knowledge of workshop practice; sympathy with the human factor; a receptive mind and an international outlook-these elements combine to produce a type of management which represents both in purpose and in method a second industrial revolution. Attention is directed to the assistance which statistical science can give in the higher control of industry, whether in budgetary matters, departmental cooperation and responsibility, planning of sales and production or costing methods, and it is pointed out 